\title{
İcra ve İflâs Hukukunda Covid-19 Sebebiyle Sürelerin Durmasına İlişkin Düzenlemelerin Kıymet Takdiri Süresine Etkisi
}

\author{
Suspension of Limitation Periods under Covid-19 Regulations and \\ Its Effects on Property Appraisal Periods in Turkish Enforcement and \\ Bankruptcy Law
}

Birce Arslandoğan ${ }^{*}$ (iD

\section{öz}

Covid-19 sebebiyle alınan adli tedbirler çerçevesinde kabul edilen 7226 sayılı Kanun geçici madde 1 hükmü ile İcra ve İflâs Kanunu ile takip hukukuna ilişkin diğer kanunlarda belirlenen süreler ve bu kapsamda hâkim veya icra ve iflâs daireleri tarafından tayin edilen sürelerin duracağı düzenlenmiştir. $\mathrm{Bu}$ çalışmada ilgili düzenlemenin K m.128a/III,c.l'de düzenlenen 'kesinleşen kıymet takdirine ilişkin olarak iki yıl geçmedikçe yeniden kıymet takdiri istenemeyeceği' kuralına etkisi değerlendirilecektir. Bu kapsamda ilk olarak, Covid-19 pandemisi sebebiyle alınan adli tedbirlere ilişkin hukuki düzenlemeler üzerinde durulacaktır. Daha sonra İcra ve İflâs Kanunu'nda düzenlenen kıymet takdiri kurumu, özellikle satış aşamasında başvurulan kıymet takdirinin işlevi tespit edilmeye çalışlacaktır. Cebri icra hukukunda kıymet takdirinin temel haklar ile ilişkisi çerçevesinde alacaklı, borçlu ve üçüncü kişi arasındaki menfaatlerin tespiti neticesinde kurumun amacı incelenerek, 7226 sayılı Kanun'un geçici madde 1 hükmünün lafzi yorumu ile İIK m.128a/III'de düzenlenmiş olan iki yıllık sürenin durması sonucuna ulaşılsa da, sürenin durmaması gerekliliği değerlendirilecektir.

Anahtar Kelimeler: Cebri icra hukuku, Covid-19, Adli tedbirler, 7226 sayılı Kanun, Kiymet takdiri, Mülkiyet hakkı, Menfaat dengesi

\section{ABSTRACT}

Limitation Periods which are defined in Enforcement and Bankruptcy Law Act No. 2004 (EBLA) and in other related acts regarding enforcement proceedings and time periods determined by court rulings and Enforcement \& Bankruptcy Offices have been suspended by the temporary Art. 1 of the Act No. 7226 as per the measures taken against Covid-19. This study examines the effect of related regulations to the rule "a new property appraisal cannot be requested within two years after an appraisal is finalized" which is defined in the first sentence of Art.128a/III of EBLA. First, the legal regulations concerning the judicial measures taken due to the Covid-19 pandemic is examined. Then, the institution of property appraisal, especially the function of appraisal requested at the sales phase is analyzed. The objective of this institution is reviewed within the context of appraisal in compulsory enforcement law, fundamental rights, and varying interests of creditors, debtors and third parties. As a result, despite the literal interpretation of the Act No. 7226 temporary Art. 1 suggesting the opposite, this article discuss the necessity of not suspending the two-year period defined in Art. 128a/III of EBLA.

Keywords: Mandatory execution processes, Covid-19, Legal precautions, Act No. 7226, Property appraisal, Property rights, Balance of Interests

* Dr. Öğretim Üyesi, İstanbul Üniversitesi Hukuk Fakültesi, Medeni Usûl ve İcra-İflâs Hukuku Anabilim Dal, ORCID: 0000-0002-5201-4987

Sorumlu Yazar/Correspondence Author: Birce Arslandoğan

E-posta/E-mail: birce@istanbul.edu.tr, 


\section{GíRiş}

2019 yılı sonunda Çin'in Wuhan kentinde başlayan Covid-19 salgının genişleyerek tüm dünyada ve Mart 2020'de ülkemizde de görülmesi üzerine 12 Mart 2019 tarihinde açıklanan ve 16 Mart 2019 tarihi itibariyle uygulanmaya başlayan tedbirlere ${ }^{1}$ ek olarak bir takım adli tedbirler alınması zorunluluğu ortaya çıkmıştır.

Bu adli tedbirler kapsamında ilk olarak İcra ve İflâs Kanunu’nun (İİK) "Fevkalade Hallerde Tatil" düzenlemeleri kapsamında "İcra Takiplerinin Durdurulması Halleri” başlıklı 330. maddesinde (m.) düzenlendiği üzere, salgın hastalık, umumi bir musibet veya harb halinde memleketin bir kısmında veya bazı iktisadi zümreler lehine muayyen bir müddet için icra takiplerinin durdurulabilmesinin ancak Cumhurbaşkanı kararı ile mümkün olması sebebiyle, 2279 sayılı "İcra ve İflâs Takiplerinin Durdurulması Hakkında Karar” başlıklı Cumhurbaşkanı Kararı kabul edilmiştir. Bu Karar’ın 1. maddesine göre, COVID-19 salgın hastalığının ülkemizde yayılmasını önlemek amacıyla alınan tedbirler kapsamında; bu Kararın yürürlüğe girdiği tarihten 30/4/2020 tarihine kadar, nafaka alacaklarına ilişkin icra takipleri hariç olmak üzere, yurt genelinde yürütülmekte olan tüm icra ve iflâs takiplerinin durdurulmasına ve bu çerçevede taraf ve takip işlemlerinin yapılmamasına, yeni icra ve iflâs takip taleplerinin alınmamasına ve ihtiyati haciz kararlarının icra ve infaz edilmemesine karar verilmiştir. Akabinde 25.03.2020 tarihli 7226 sayılı Kanun’un Geçici 1. maddesi ile adli tedbirler kapsamında ikinci bir düzenleme kabul edilmiştir³. Son olarak ise 2480 sayılı "Yargı Alanındaki Hak Kayıplarının Önlenmesi Amacıyla Getirilen Durma Süresinin Uzatılmasına Dair Karar” başlıklı Cumhurbaşkanı Kararı ${ }^{4}$ ile Covid-19 salgın hastalığının ülkemizde yayılmasını ve yargı alanında doğabilecek hak kayıplarını önlemek amacıyla, 7226 sayılı Bazı Kanunlarda Değişiklik Yapılmasına Dair Kanunun geçici linci maddesinin birinci fikrasında düzenlenen durma süresi, 01.05.2020 (bu tarih dâhil) tarihinden 15.06.2020 (bu tarih dâhil) tarihine kadar (salgın hastalığın yayılma tehlikesinin daha önce ortadan kalkması halinde yeniden değerlendirilmek üzere) uzatılmıştır ${ }^{5}$.

Çalışmamızda "Kıymet takdirine ilişkin şikâyet" başlıklı İIK m.128a/III,c.1'de yer alan, kesinleşen kıymet takdirinin yapıldığ istenemeyeceğine ilişkin hükmün Covid-19 salgını kapsamında kabul edilen adli tedbirlere ilişkin hukuki düzenlemeler kapsamında ne şekilde değerlendirilmesi gerektiği konu edilmiştir.

1 İç İşleri Bakanlığı’nın çıkardığı genelgelerle uygulanan bu tedbirlerin kanuni dayanaklarının İl İdaresi Kanunu’nun 11. maddesinin C fikrası ile Umumi Hıfzısıhha Kanunu'nun 27. ve 72. maddeleri olarak gösterilmesine ve özellikle de sokağa çıkma kısıtlamalarının 1982 Anayasası’na uygunluğunun değerlendirilmesine ilișkin olarak ayrıntılı bilgi için bkz. Volkan Aslan, 'COVID-19 Salgını Sebebiyle Uygulanan Sokağa Çıkma Kısıtlamalarının 1982 Anayasası’na Uygunluğu', (2020) LXXVIII (2), İstanbul Hukuk Mecmuası 809-835.

22279 sayılı Cumhurbaşkanı Kararı, Kabul Tarihi: 21.03.2020, Yürürlüğe Giriş Tarihi: 22.03.2020 (RG 22.03.2020, S 31076).

37226 sayılı Bazı Kanunlarda Değişiklik Yapılmasına Dair Kanun, Kabul Tarihi: 25.03.2020, Yürürlügü Giriş Tarihi: 26.03.2020 (RG 26.03.2020, S 31080 Mükerrer).

42480 sayılı Cumhurbaşkanı Kararı, Kabul Tarihi: 29.04.2020, Yürürlüğe Giriş Tarihi: 30.04.2020, (RG 30.04.2020, S 31114).

54734 sayılı Kamu İhale Kanunu ve ikincil mevzuatında öngörülen zorunlu idari başvuru yoluna ilişkin süreler 2480 sayılı Cumhurbaşkanı Kararı’nın kapsamında dahil edilmemiştir. 
$\mathrm{Bu}$ amaçla ilk olarak adli tedbirlere ilişkin düzenlemelerin kapsamı ele alınacak, arkasından İ̇K m.128a/III hükmünün niteliği değerlendirilecektir. Son olarak ise, kesinleşen bir kıymet takdirinin yenilenmesinden önce geçmesi gereken iki yıllık sürenin bu düzenlemeler kapsamındaki yeri incelenerek, adli tedbirlere ilişkin düzenlemeler kapsamında durup durmadığı tespit edilecektir.

\section{ADLi TEDBíRLERE iLIŞKIN OLARAK GETIRILEN HUKUKI DÜZENLEMELER}

\section{A. 2279 SAYILI "ICRA VE IFLÂS TAKIPLERININ DURDURULMASI HAKKINDA KARAR" BAŞLIKLI CUMHURBAŞKANI KARARI}

İIK m.330’a göre, salgın hastalık, umumi bir musibet veya harb halinde Cumhurbaşkanı karariyle memleketin bir kısmında veya bazı iktisadi zümreler lehine muayyen bir müddet için icra takipleri durdurulabilecektir. Bu maddeye göre, icra takiplerinin durdurulmasına ilişkin olarak varlığı aranan ilk şart olağanüstü durumların varlığıdır ki bu hususa ilişkin olarak madde metninde salgın hastalık, umumi bir musibet veya harb hali örnek olarak sayılmıştır ${ }^{6}$. İkinci olarak ise bu hükmün uygulanabilmesi için Cumhurbaşkanı Kararı̀nın varlığının gereklidir ${ }^{7}$.

2279 sayılı Cumhurbaşkanı Kararı ile İ̇K m.330 hükmünün uygulanabilmesi için gerekli olan şartlar oluşmuş ve İİK’nın yürürlüğe girmesinden bu yana, madde 330 ilk defa uygulama alanı bulmuştur ${ }^{8}$. Hatta İ̇K m.330 hükmü ile fevkalâde hallerde sadece başlamış olan icra takiplerinin durması kabul edilmiş iken, 2279 sayılı Cumhurbaşkanı Kararı ile sadece başlamış olan icra takiplerinin değil, tüm icra ve iflâs takiplerinin durdurulmasına ve bu çerçevede taraf ve takip işlemlerinin yapılmamasına, yeni icra ve iflâs takip taleplerinin alınmamasına ve ihtiyati haciz kararlarının icra ve infaz edilmemesine karar verilerek, İIK m.330 hükmünün uygulama alanı genişletilmiştir9 9

İlgili Cumhurbaşkanı Kararı ile icra ve iflâs takiplerinin durdurulmasına ilişkin bu tedbirin 22.03.2020 tarihinden 30.04.2020 tarihine kadar geçerli olacağı da hükme bağlanmıştır.

\section{B. 7226 SAYILI BAZI KANUNLARDA DEĞişiKLIK YAPILMASINA DAIR KANUN'UN GEÇICI I. MADDESI}

Adli tedbirlere ilişkin ikinci olarak 7226 sayılı Bazı Kanunlarda Değişiklik Yapılmasına Dair Kanun’un Geçici 1. maddesi düzenlemesi getirilmiştir. Bu düzenleme ile hem yargılama hukukundaki hem de icra ve iflâs hukukundaki sürelere ilişkin birtakım tedbirlerin alınması öngörülmüştür.

6 Ejder Yılmaz, 'Olağanüstü Durumlarda Borçlulara Süre Verilmesi ve İcra Takiplerinin Durdurulması', (1977) IX BATIDER 153-191, 181.

7 Yllmaz (n 6) 181; Taylan Özgür Kiraz, 'Fevkalâde Hallerde Mühlet ve Tatil (İIK. md.317-330)', (2000) 73 (2) Manisa Barosu Dergisi 7-20, 12; Baki Kuru, İcra ve İflas Hukuku El Kitabı (2. Baskı, Adalet 2013) 1583 (El Kitabı); Murat Atalı, İbrahim Ermenek ve Ersin Erdoğan, İcra ve İflas Hukuku (3. Bası, Yetkin Yayınları 2020) s 79.

8 Kararın uygulama alan ve kapsamına ilişkin ayrıntılı bilgi için bkz. Hakan Pekcanıtez, '2279 sayılı Cumhurbaşkanı (Fevkalâde Mühlet) Kararı ile 7226 sayılı Kanun’un Geçici 1. maddesinin Birlikte Değerlendirilmesi, in Muhammet Özekes (ed), Covid-19 salgınının Hukuki Boyutu-Hukukun Tüm Alanlarında Değerlendirmeler (On İki Levha 2020) 143-157, 143 (Covid).

9 Pekcanitez, Covid (n 8) 144. 
7226 sayılı Kanun'un geçici madde 1/I hükmü, Covid-19 salgın hastalığının ülkemizde görülmüş olması sebebiyle yargı alanındaki hak kayıplarının önlenmesi amacıyla medeni usûl ve icra iflâs hukukuna ilişkin tedbirlerin kapsamı belirlenmiştir. Geçici madde 1/I hükmünün (a) bendi ile yargılama hukukuna (idari, ceza ve medeni yargılama) ilişkin tedbirlerin kapsamı belirlenmiş iken aynı fikranın (b) bendi ile icra ve iflâs hukukuna ilişkin alınacak tedbirlerin çerçevesi çizilmiştir. İlgili maddenin ikinci fikrasında 3 bend halinde hangi sürelerin bu maddenin kapsamı dışında kaldığ düzenlenmiştir. Maddenin üçüncü fikrasında 2004 sayılı Kanun ile takip hukukuna ilişkin diğer kanunlar kapsamında bazı durumlar ve tedbirler düzenlenmiş ve dördüncü ve son fikra ile de durma süresince duruşmaların ve müzakerelerin ertelenmesi de dâhil olmak üzere alınması gereken tüm diğer tedbirlerin ve buna ilişkin usul ve esasların hangi kurumlar tarafından belirleneceği hükme bağlanmıştır ${ }^{10}$.

\section{2480 SAYILI "YARGI ALANINDAKI HAK KAYIPLARININ ÖNLENMESI AMACIYLA GETIRILEN DURMA SÜRESININ UZATILMASINA DAIR KARAR" BAŞLIKLI CUMHURBAŞKANI KARARI}

29 Nisan 2020 tarihinde kabul edilerek 30 Nisan 2020 tarihinde yürürlüğe giren 2480 sayılı Cumhurbaşkanı Kararı, aslen duran işlemlerin ve sürelerin türü yönünden yeni bir düzenleme getirmeksizin, 7226 sayılı Kanun'un geçici madde 1 hükmü ile 30.04 .2020 tarihine kadar duran

107226 sayılı Kanun’un Geçici Madde 1 hükmü şu şekildedir: “(1) Covid-19 salgın hastalığının ülkemizde görülmüş olması sebebiyle yargı alanındaki hak kayıplarının önlenmesi amacıyla; a) Dava açma, icra takibi başlatma, başvuru, şikâyet, itiraz, ihtar, bildirim, ibraz ve zamanaşımı süreleri, hak düşürücü süreler ve zorunlu idari başvuru süreleri de dâhil olmak üzere bir hakkın doğumu, kullanımı veya sona ermesine ilişkin tüm süreler; 6/1/1982 tarihli ve 2577 sayılı İdari Yargılama Usulü Kanunu, 4/12/2004 tarihli ve 5271 sayılı Ceza Muhakemesi Kanunu ve 12/1/2011 tarihli ve 6100 sayılı Hukuk Muhakemeleri Kanunu ile usul hükmü içeren diğer kanunlarda taraflar bakımından belirlenen süreler ve bu kapsamda hâkim tarafından tayin edilen süreler ile arabuluculuk ve uzlaştırma kurumlarındaki süreler 13/3/2020 (bu tarih dâhil) tarihinden, b) 9/6/1932 tarihli ve 2004 saylı İcra ve İflâs Kanunu ile takip hukukuna ilişkin diğer kanunlarda belirlenen süreler ve bu kapsamda hâkim veya icra ve iflâs daireleri tarafından tayin edilen süreler; nafaka alacaklarına ilişkin icra takipleri hariç olmak üzere tüm icra ve iflâs takipleri, taraf ve takip işlemleri, yeni icra ve iflâs takip taleplerinin alınması, ihtiyati haciz kararlarının icra ve infazına ilişkin işlemler 22/3/2020 (bu tarih dâhil) tarihinden, itibaren 30/4/2020 (bu tarih dâhil) tarihine kadar durur. Bu süreler, durma süresinin sona erdiği günü takip eden günden itibaren işlemeye başlar. Durma süresinin başladığı tarih itibarılya, bitimine on beş gün ve daha az kalmış olan süreler, durma süresinin sona erdiği günü takip eden günden başlamak üzere on beş gün uzamış sayılır. Salgının devam etmesi halinde Cumhurbaşkanı durma süresini altı ayı geçmemek üzere bir kez uzatabilir ve bu döneme ilişkin kapsamı daraltabilir. Bu kararlar Resmî Gazete’de yayımlanır. (2) Aşağıdaki süreler bu maddenin kapsamı dışındadır: a) Suç ve ceza, kabahat ve idari yaptırım ile disiplin hapsi ve tazyik hapsi için kanunlarda düzenlenen zamanaşımı süreleri. b) 5271 sayılı Kanunda düzenlenen koruma tedbirlerine ilişkin süreler. c) 6100 sayılı Kanunda düzenlenen ihtiyati tedbiri tamamlayan işlemlere ilişkin süreler. (3) 2004 sayılı Kanun ile takip hukukuna ilişkin diğer kanunlar kapsamında; a) İcra ve iflâs daireleri tarafından mal veya haklara ilişkin olarak ilan edilmiş olan satış gününün durma süresi içinde kalması halinde, bu mal veya haklar için durma süresinden sonra yeni bir talep aranmaksızın icra ve iflâs dairelerince satış günü verilir. Bu durumda satış ilanı sadece elektronik ortamda yapılır ve ilan için ücret alınmaz, b) Durma süresi içinde rızaen yapılan ödemeler kabul edilir ve taraflardan biri, diğer tarafın lehine olan işlemlerin yapılmasını talep edebilir, c) Konkordato mühletinin alacaklı ve borçlu bakımından sonuçları, durma süresince devam eder, ç) İcra ve iflâs hizmetlerinin aksamaması için gerekli olan diğer tedbirler alınır. (4) Durma süresince duruşmaların ve müzakerelerin ertelenmesi de dâhil olmak üzere alınması gereken diğer tüm tedbirler ile buna ilişkin usul ve esasları; a) Yargıtay ve Danıştay bakımından ilgili Başkanlar Kurulu, b) İlk derece adli ve idari yargı mercileri ile bölge adliye ve bölge idare mahkemeleri bakımından Hâkimler ve Savcılar Kurulu, c) Adalet hizmetleri bakımından Adalet Bakanlığı, belirler.". 
süreleri 01.05.2020 (bu tarih dâhil) tarihinden 15.06.2020 (bu tarih dâhil) tarihine kadar ve salgın hastalığın yayılma tehlikesinin daha önce ortadan kalkması halinde yeniden değerlendirilmek üzere uzatmıştır.

\section{DEĞERLENDIRME}

2279 sayılı Cumhurbaşkanı Kararı ve 7729 sayılı Kanun’un geçici madde 1 düzenlemesinin uygulanması ve yürürlügünü bir arada değerlendirmek gerekmektedir ${ }^{11}$. İİK m.330'de düzenlenen icra takiplerinin durmasına ilişkin düzenlemenin 2279 sayılı Cumhurbaşkanı Kararı ile uygulamaya konulduğu ancak kısa bir süre sonra kabul edilen 7226 sayılı Kanun’un geçici 1. maddesinin yürürlüğe girmesi ile bu düzenlemenin normlar hiyerarşisinde Cumhurbaşkanı düzenlemesinden önce gelmesi ve hem zamansal olarak daha sonra hem nitelik itibariyle özel bir düzenleme olması itibariyle, hem İIK m.330'un hem de 2279 sayılı Cumhurbaşkanı Kararı’nın uygulama alanının kalmadığı sonucuna ulaşmak gerecektir ${ }^{12}$.

Her iki hukuki düzenleme bakımından da icra ve iflâs hukukunun ilgilendiren tedbirlere ilişkin durma süresinin 22.03.2020 (bu tarih dâhil) tarihinden 30.04.2020 (bu tarih dâhil) tarihine kadar olduğu sabittir. Ancak bu durma süreleri üçüncü bir düzenleme olan ve 30 Nisan 2020 tarihinde yürürlüğe giren 2480 sayılı Cumhurbaşkanı Kararı ile 01.05.2020 (bu tarih dâhil) tarihinden 15.06.2020 (bu tarih dâhil) tarihine kadar uzatılmıştır. Buna bağlı olarak ortaya sürelerin durması bakımından ortaya çıkan nihai zaman aralığı 22.03.2020 (bu tarih dâhil) ile 15.06.2020 (bu tarih dâhil) şeklinde değerlendirmek gerekmektedir.

\section{ADLi TEDBIRLERE íLişKIN HUKUKi DÜZENLEMELER ÇERÇEVESINDE ALINAN ICRA VE IFLÂS HUKUKUNA ILIŞKIN TEDBIRLERIN TESPIT EDILMESi}

7226 sayılı Kanun'un geçici madde 1/I, b. (b) hükmüne göre, 09.06.1932 tarihli ve 2004 sayılı İcra ve İflâs Kanunu ile takip hukukuna ilişkin diğer kanunlarda belirlenen süreler ve bu kapsamda hâkim veya icra ve iflâs daireleri tarafından tayin edilen süreler; nafaka alacaklarına ilişkin icra takipleri hariç olmak üzere tüm icra ve iflâs takipleri, taraf ve takip işlemleri, yeni icra ve iflâs takip taleplerinin alınması, ihtiyati haciz kararlarının icra ve infazına ilişkin işlemler 22/3/2020 (bu tarih dâhil) tarihinden itibaren 30/4/2020 (bu tarih dâhil) tarihine kadar durur.

Buna göre, kısaca özetlemek ve gruplamak gerekirse icra ve iflâs hukukuna ilişkin olarak alınan tedbirler, takip hukukuna ilişkin olarak kanun ile, hâkim ve icra iflâs daireleri tarafından belirlenen

112279 sayılı Cumhurbaşkanı Kararı ile 7226 sayılı Kanun arasındaki uygulama sorunu, normlar hiyerarşisi ve zaman bakımından uygulamaya ilişkin olarak ayrıntılı bilgi için bkz. Oğuz Atalay ve Muhammet Özekes, '7226 Sayılı Kanun ile İcra ve İflâs Kanunu m.330 Hükmünü Uygulayan Cumhurbaşkanlığı Kararı (2279 Sayılı) Çerçevesinde Ortaya Çıkan Bazı Sorular ve Tartışmalara Cevaplar', in Muhammet Özekes (ed), Covid-19 salgınının Hukuki Boyutu-Hukukun Tüm Alanlarında Değerlendirmeler, (On İki Levha 2020), 159-186, 163 vd.

12 Pekcanıtez, Covid (n 8) 146; Atalay ve Özekes (n 11) 163; Aziz Serkan Arslan, 'Covid-19 Salgını Sebebiyle İcra Takiplerine İlişkin Düzenlemelerin Değerlendirilmesi', (2020) (148) TBB Dergisi, 197-234, 205; Murat Atalı ve Ersin Erdoğan, 'COVID-19 Salgınının İcra ve İflâs Hukuku Alanına Etkileri', (2020) LXXVIII (2) İstanbul Hukuk Mecmuası, 395-416, 401. 
süreler, tüm icra ve iflâs takipleri (nafaka alacaklarına ilişkin icra takipleri hariç olmak üzere), taraf ve takip işlemleri, yeni icra ve iflâs takiplerinin alınması ve son olarak ihtiyati haciz kararlarının icra ve infazlarını durmasıdır.

\section{III. iik M.I 28A/III DÜZENLEMESi}

\section{A. ANA HATLARI ILE KIYMET TAKDIRI}

Kıymet takdiri kavramı İcra ve İflâs Kanunu’nda tanımlanmış bir kavram olmadı̆̆ı gibi yargı kararlarında da kıymet takdirinin tanımına yer verilmiş değildir. Bununa beraber, öğretide kıymet takdiri, icra hukuku bakımından 'hacze konu olan taşınır ve taşınmaz eşyanın haciz miktarı veya satışa esas tutarının belirlenmesi amacıyla yetkili kişiler tarafından yapılan icra takip işlemi niteliğindeki ${ }^{13}$ değer belirleme faaliyeti' olarak tanımlanmaktadır ${ }^{14}$. Taşınmaz mallarda kıymet takdiri haciz ve satış aşamalarında olmak üzere iki defa yapılmaktadır ve kıymet takdirinin işlevi de kıymet takdirinin yapılış zamanına göre değişiklik göstermektedir ${ }^{15}$.

İcra ve İflâs Kanunu'nda icra takipleri bakımından iki farklı aşamada kıymet takdiri yapılması öngörülmüştür. Bunlardan biri haciz aşamasında kıymet takdiri yapılmasıdır ki bu aşamada kıymet takdiri yapılmasının amacı satış aşamasında kıymet takdiri yapılmasından farklıdır. Haciz aşamasında kıymet takdiri yapılmasının amacı, takip konusu alacak, işlemiş faiz ve takip masraflarını karşılayabilecek malların haczedilip haczedilmediğinin tespit edilmesidir ki bu sayede bir yandan alacaklının alacağına tam olarak kavuşması sağlanırken diğer yandan borçlunun borcundan fazla ekonomik değere sahip malının haczi engellenmektedir ${ }^{16}$. Kıymet takdirinin yapılması ikinci olarak satış aşamasında söz konusu olmaktadır ki bu aşamada kıymet takdiri yapılmasının asıl işlevi satışın en az hangi bedel ile yapılacağının saptanmasıdır ${ }^{17}$.

Çalışmamızın konusunu 128a/III düzenlemesinin 7226 sayılı Kanun'un geçici madde l'e göre yorumlanması teşkil ettiğinden, konu kapsamında sadece taşınmazların satış aşamasındaki kıymet takdiri ve bu aşamadaki kıymet takdirinin kesinleşmesine bağlanan sonuçlar ilgili olduğu çerçeve incelenecektir.

13 Kıymet takdirinin icra takip işlemi olarak nitelendirilmesine ilişkin olarak doktrinde farklı görüşler mevcuttur. Kıymet takdiri işleminin hukuki niteliğine ilişkin ayrıntılı bilgi için bkz. Nilüfer Boran Güneysu, İcra Hukukunda Taşınmazların Kiymet Takdiri (Yetkin Yayınları 2020) $116 \mathrm{vd.}$

14 Boran Güneysu (n 13) 28.

15 ibid 61.

16 Kuru, El Kitabı (n 7) 421; Hakan Pekcanıtez, Oğuz Atalay, Meral Sungurtekin-Özkan ve Muhammet Özekes, İcra ve İflas Hukuku (7. Bası, On İki Levha Yayıncılık 2020) 156; Ramazan Arslan, Ejder Yılmaz, Sema Taşpınar-Ayvaz ve Emel Hanağası, İcra ve İflas Hukuku (6. Bask1, Yetkin Yayınlar1 2020) 251; Murat Dönmez, İcra ve İflâs Hukukunda Taşınmaz Malların Paraya Çevrilmesi (Vedat Kitapçılık 2010) 186 vd.; Haciz aşamasında yapılan kıymet takdirinin işlevine ilişkin ayrıntılı bilgi için bkz. Boran Güneysu (n 13) 61 vd.

17 Kuru, El Kitabı (n 7) 659 dn. 63; Boran Güneysu (n 13) 69-70; Taşınmazların satışı aşamasında kıymet takdirinin diğer işlevleri bakımından ayrıntılı bilgi için bkz. Boran Güneysu (n 13) 71 vd. 


\section{B. KIYMET TAKDIRININ KESINLEŞMESI VE KESINLEŞMESINE BAĞLANAN SONUÇLAR}

'Kıymet takdirine ilişkin şikâyet' başlıklı İIK m.128a hükmü ile kıymet takdirine karşı başvurulabilecek hukuki bir imkân olarak şikâyet yolu düzenlenmiş ve kötü niyetle yetkisiz icra dairesine yapılan şikâyet başvurularının ve takibin gecikmesine neden olan davranışların engellenmesi amaçlanmıştır ${ }^{18}$.

Hukuki çare olarak şikâyet yolunda süresinde başvurulmaması veya icra mahkemesinin şikâyet başvurusunu reddetmesi üzerine satış aşamasında kıymet takdiri kesinleşmiş olacaktır ${ }^{19}$. Benzer şekilde, icra mahkemesine kıymet takdirine ilişkin şikâyet başvurusu yapıldığı ve bunun neticesinde satı̧a çıkacak taşınmazın kıymetinin farklı takdir edilmesi suretiyle de kıymet takdirinin kesinleşmesi söz konusu olabilecektir.

Hükmün üçüncü fikrasında "Kesinleşen kıymet takdirinin yapıldığ 1 tarihten itibaren iki yıl geçmedikçe yeniden kıymet takdiri istenemez. Ancak, doğal afetler ve imar durumundaki çok önemli değişiklikler meydana getiren bazı hallerde yeniden kıymet takdiri istenebilir." hükmü bulunmaktadır. İlgili düzenlemeye göre, kesinleșen kıymet takdirinin yapıldığı tarihten itibaren iki yıl geçmedikçe, yeniden kıymet takdiri yapılması istenemeyecektir. Buna bağlı olarak da bu iki yıllık süre içerinde taşınmazın satılacak olması halinde, kıymet takdirinin yeniden yapılmasına gerek olmayacaktır ${ }^{20}$.

Madde hükmünde yer alan iki yıllık sürenin başlangıç tarihinin ne olması gerektiğine ilişkin olarak doktrin ve uygulamada farklı görüşler mevcuttur.

Doktrinde, kıymet takdirine karşı şikâyet yoluna başvurulduğu hallerde, iki yıllık sürenin, kıymet takdiri bedelinin aynı çıkması veya talebin reddi halinde icra dairesince belirlenen tarihten ve şikâyet talebinin kabul edilip kıymetin icra mahkemesi tarafından belirlenmesi halinde ise, icra mahkemesince yaptırılan keşif tarihinden itibaren iki yıllık sürenin işlemeye başlaması gerektiği savunulmaktadır ${ }^{21}$.

Maddede düzenlenen iki yıllık sürenin başlangıcının, madde metninden kıymet takdirinin yapıldığı tarih olarak anlaşıldığı ancak, bu halde, kıymet tarihinin kesinleşmesine kadar geçecek olan sürenin de bu iki yılın içerisinde hesaplanmasının lazım geldiğini ve bu durumda da sürenin yapılan şikâyet başvurusundan icra mahkemesinin karar vermesine kadar kısalmış olacağını ve bu sonucun ise taraf menfaatleri ile bağdaşmayacağı dolayısı ile takibin de sürüncemede bırakılmaması için, kıymet takdirinin kesinleşmesinden itibaren hesaplanması gerektiği ileri sürülmüştür ${ }^{22}$.

18 İIK m.128a hükmü ile getirilen değişikliklere ilişkin ayrıntılı bilgi için bkz. Hakan Pekcanıtez, '4949 sayılı Kanun'la, İcra Hukukunda Yapılan Değiş̧ikliklerin Değerlendirilmesi’ (2003) (49) TBB Dergisi, 137-258, 152-153 (Değişiklik); Mert Namlı, İcra Hukukunda Taşınmaz Malların Haczi ve Paraya Çevrilmesi (On İki Levha Yayıncılık 2019) 470; Boran Güneysu (n 13) 206-207.

19 Namlı (n 18) 472; Boran Güneysu (n 13) 204-205.

20 Baki Kuru, İcra ve İflas Hukuku, C. II (3. Bask1, Evrim 1990) 1298; Namlı (n 18) 473-474; Boran Güneysu (n 13 ) 215.

21 Mustafa Oskay, Coşkun Koçak, Adnan Deynekli ve Ayhan Doğan, İIK Şerhi (Madde 100-176/b), C. 3 (Turhan Kitapevi 2007) 3152; Dönmez (n 16) 194-195; Boran Güneysu (n 13) 210.

22 Pekcantez, Değişiklik (n 18) 153. 
Yargıtay, kıymet takdirinin kesinleşmesi bakımından iki yıllık sürenin başlangıç tarihinin kıymet takdirinin fiilen gerçekleştiği tarihten itibaren işlemeye başlayacağı kanaatindedir ${ }^{23}$. Kıymet takdirine karşı hukuki çare olarak şikâyet yoluna başvurulmadığı halde, sürenin başlangıcının icra memuru ile bilirkişilerin taşınmazın bulunduğu yere fiilen gittikleri tarih olacaktır ${ }^{24}$. Kıymet takdirine karşı hukuki çare olarak şikâyet yoluna başvurulmuş ve şikâyet başvurusunun da kabul edildiği hallerde ise, iki yıllık süre, hâkimin bilirkişiler ile keşif yaptığı tarihten itibaren işlemeye başlayacaktır ${ }^{25}$.

Kıymet takdirinin kesinleşmesinin en önemli sonucu, madde metninde düzenlendiği üzere, kesinleşen kıymet takdirinin yapıldığı tarihten itibaren ancak iki yıl geçmesi halinde yeniden kıymet takdiri yapılmasının istenebilecek olmasıdır. İki yıllık süre içerisinde taşınmazın satılacak olması halinde ise, yeniden kıymet takdiri yapılmasına gerek olmayacaktır. Aksi durum, Yargitay tarafından ihalenin feshi sebebi olarak kabul edilmektedir ve bu düzenlemenin kamu düzenine ilişkin olması sebebiyle mahkemenin bu hususu re’sen gözetmesi gerekmektedir ${ }^{26}$.

\section{7226 SAYILI KANUN GEÇICI MADDE I HÜKMÜ'NÜN KESINLEŞEN KIYMET TAKDIRINDE SÜREYE ETKISININ DEĞERLENDIRILMESi}

\section{A. MESELENIN ORTAYA KONULMASI}

7226 sayılı Kanun'un geçici madde 1 hükmü ile İcra ve İflâs Kanunu ile takip hukukuna ilişkin diğer kanunlarda belirlenen süreler ile bu kapsamda hâkim veya icra ve iflâs daireleri tarafindan tayin edilen sürelerin 22/3/2020 (bu tarih dâhil) tarihinden itibaren 30/4/2020 (bu tarih dâhil) tarihine kadar durması düzenlenmiştir. Daha sonra 2480 sayılı Cumhurbaşkanı Kararı ile 01.05.2020 (bu tarih dâhil) tarihinden 15.06.2020 (bu tarih dâhil) tarihine kadar bu durma süreleri uzatılmıştır.

İcra ve İflâs Kanunu m.128a/III,c.l'de yer alan kesinleşen kıymet takdirinin yapıldığı tarihten itibaren iki yll geçmedikçe yeniden kıymet takdiri istenemeyeceği düzenlemesinde yer alan iki yıllık sürenin de 7226 sayılı Kanun’un geçici madde 1 hükmü düzenlemesi gereğince durduğu doktrinde savunulmaktadır ${ }^{27}$.

23 Yargitay 12. HD, E 2013/5132, K 2013/12849, T 04.04.2013; Yargitay 12. HD, E 2015/28132, K 2015/30325, T 03.12.2015; Yargitay 12. HD, E 2017/1055, K 2017/5645, T 06.04.2017 (Lexpera Hukuk Bilgi Sistemi, Erişim Tarihi: 28.02.2021).

24 Yargitay 12. HD, E 2007/2908, K 2007/5536, T 23.03.2007; Yargitay 12. HD, E 2007/6021, K 2007/8400, T 27.04.2007 (Lexpera Hukuk Bilgi Sistemi, Erişim Tarihi: 26.02.2021).

25 Yargitay 12. HD, E 2006/15691, K 2006/19176, T 13.10.2006; Yargitay 12. HD, 2011/10638, K 2011/29421, T 19.12.2011 (Lexpera Hukuk Bilgi Sistemi, Erişim Tarihi: 26.02.2021).

26 Namlı (n 18) 473; Boran Güneysu (n 13) 206; Yargitay 12. HD, E 2014/990, K 2013/3397, T 11.02.2014; Yargitay 12. HD, E 2016/1082, K 2016/6895, T 09.03.2016; Yargitay 12. HD, E 2017/8478, K 2017/16001, T 22.12.20172011 (Lexpera Hukuk Bilgi Sistemi, Erişim Tarihi: 20.02.2021).

27 Atalay ve Özekes (n 11) 173; Hakan Pekcanıtez ve Evrim Erişir, 'Koronavirüs (Covid-19) Salgınına Karşı Alınan, MedeniUsûl ve İcra İflâs Hukukunu İlgilendiren Önlemler' (Legal Blok, 3 Haziran 2020) < https://legal.com.tr/blog/ genel/koronavirus-covid-19-salginina-karsi-alinan-medeni-usul-ve-icra-iflas-hukukunu-ilgilendiren-onlemler/ > Erişim Tarihi 14 Şubat 2020. 
7226 sayılı Kanun geçici madde 1 düzenlemesinin lafzinin İcra ve İflâs Kanunu’nda düzenlenen tüm sürelerin durması olduğu ve İIKK m.128a/III,c.1 hükmünün de İcra ve İflâs Kanunu düzenlemesi olması itibariyle hükümdeki iki yıllık sürenin de Covid-19 adli tedbirleri kapsamında durması gerektiği sonucuna ulaşılabilecek ise de kıymet takdiri yapılmasının işlevi ve İ̈K m.128a/III hükmünün icra hukukundaki menfaatler dengesi çerçevesinde değerlendirilmesi sonucunda, farklı bir değerlendirme yapılabilmesi mümkün olabilir mi?

\section{B. KIYMET TAKDIRININ MÜLKIYET HAKKI ILE SIKI IRTIBATI}

İ́K m.128a maddesine konu olan kıymet takdiri aslen hacizli malın değerini belirleme faaliyetidir ve bu işlemin sonunda parasal bir değer olan ve satış aşamasında malın değerinin belirlenmesi bakımından önem arz eden kıymet tutarına ulaşılır ${ }^{28}$.

Cebri icra faaliyetinin egemenlik yetkisinin kullanımına ilişkin olduğu ve bu faaliyetin de temelini ve gücünü Anayasa'dan almakta olduğu göz önüne alındığında, bu husus cebri icra organlarının işlemlerinin Anayasa’ya uygun olması zorunluluğunu ortaya çıarmaktadır ${ }^{29} \mathrm{ki}$ bunun doğal bir sonucu olarak cebri icra işlemi olarak nitelendirilen kıymet takdiri işleminin de Anayasàya uygun olması gerekir ${ }^{30}$.

Taşınmazın gerçek değerinin belirlenmesi amacını taşıyan kıymet takdiri, bu amacı sebebiyle takip alacaklısı, takip borçlusu ve hatta üçüncü kişilerin mülkiyet hakkını doğrudan ilgilendirmektedir ${ }^{31}$ ve mutlak bir koruma sağlayan mülkiyet hakkı, Anayasa m.35 hükmü ile düzenlenmiştir.

Cebri icra hukukunda bu koruma genel olarak, alacaklı bakımından, borçlu tarafından ihlal edilmiş olan mülkiyet hakkına (malvarlığına) yeniden kavuşması ve alacağını elde etmesi, hakkının engellenmemesi şeklinde ortaya çıkacaktır ${ }^{32}$. Borçlu bakımından ise mülkiyet hakkının korunması, borçlunun malvarlığından mahrum bırakılmaması, malvarlı̆̆ına karşı haksız, ölçüsüz ve menfaat dengesini bozan müdahaleler ile malvarlığının haraç mezat satılmaması şeklinde ortaya çıkmaktadır ${ }^{33}$. Üçüncü kişilerin mülkiyet hakkı ise (ki bu kişiler esasen takibin tarafı değillerdir) malvarlıklarına müdahale edilmeyeceğinden emin olma ve haksız müdahaleleri ortadan kaldırabilme imkanları ile korunmaktadır ${ }^{34}$.

Mülkiyet hakkının korunması gerekliliği çerçevesinde, kıymet takdirinin de alacaklı, borçlu ve üçüncü kişi bakımından olmak üzere üçlü bir fonksiyonunun olduğu sonucuna ulaşmak gerekecektir.

28 Boran Güneysu (n 13) 28.

29 Muhammet Özekes, 'İcra Hukukunda Temel Haklar ve İlkeler, (Adalet 2009) 21 (Temel Haklar); Pınar Çiftçi, İcra Hukukunda Menfaat Dengesi (Adalet 2010) 49-50.

30 Boran Güneysu (n 13) 29.

31 Özekes, Temel Haklar (n 29) 183-184; Boran Güneysu (n 13) 30.

32 Özekes, Temel Haklar (n 29) 182.

33 ibid 182-183.

34 ibid 183. 
Kıymet takdirinin ana işlevi satış aşamasında taşınmazın gerçek değerinin belirlenmesidir ve bu işlev aslen mülkiyet hakkının korunmasına hizmet eder.

Kıymet takdirinin amacı olan taşınmazın gerçek değerinin belirlenmesi, alacaklının alacağına tam olarak kavuşmasını sağlar ${ }^{35}$. Taşınmazın gerçek değerinin belirlenmesi borçlu bakımından da malvarlığının, takipte değerinin çok altında satılmaması bakımından önemlidir ve bu belirleme, taşınmazın haraç mezat satılmasının önlenerek, borçlunun mülkiyet hakkının korunmasına hizmet eder. Ayrıca, borçlunun borcunu mümkün olduğu kadar fazla miktarda ödeyebilmesi, borçlunun daha sonra edindiği mallar üzerindeki mülkiyet hakkını da koruyucu niteliktedir lakin alacağını tam olarak alamayan alacaklının, borçlunun yeni edindiği mallarına haciz koydurma imkânı devam etmektedir ${ }^{36}$. Son olarak ise taşınmazın gerçek değerinin tespiti, taşınmaz üzerinde sınırlı aynî hak sahiplerinin veya asıl borca karşılık, üçüncü kişinin verdiği ipoteklerin söz konusu olduğu hallerde taşınmaz sahibinin (ki takip bakımından üçüncü kişi olarak nitelendirilir) mülkiyet hakkını koruyucu niteliktedir ${ }^{37}$.

Görülmektedir ki İİK’daki kıymet takdirine ilişkin düzenlemeler aslen Anayasa ile korunan mülkiyet hakkının korunmasına hizmet eden düzenlemelerdir. Kıymet takdirinin yapılması ve bu yolla satışa konu olacak taşınmazın gerçek değerinin tespiti hem alacaklı hem borçlu hem de üçüncü kişilerin menfaatini koruyucu niteliktedir.

\section{C. іiK M.I28A/III HÜKMÜNÜN DÜZENLENME AMACI}

İcra ve İflâs Kanunu m.128a/III, c.1 hükmünde yer alan kesinleşen kıymet takdiri için iki yıl geçmedikçe yeniden kıymet takdiri istenemeyeceğine ilişkin düzenlemede yer alan iki yıllık sürenin 7226 sayılı Kanun'un geçici madde 1 hükmü ile durup durmayacağı tespiti yapılırken hukukta menfaat dengelerinin korunmasına ilişkin değerlendirme yapılması ve ilgili normun amacına uygun yorumlanması gerekliliği vardır.

Dolayısı ile 128a/III, c.l'de yer alan iki yıllık sürenin getiriliş amacından yola çıkarak mevcut koşulların değerlendirilmesi ve bu çerçevede bir sonuca varılması zorunluluğu doğmaktadır.

Cebri icra hukukuna ilk olarak İIK m.128 hükmüne eklenen 'Kesinleşen kıymet takdiri için iki y1 geçmedikçe yeniden kıymet takdiri istenemez. düzenlemesi ${ }^{38}$ daha sonraki yıllarda 128 a hükmünün kabulü ile ${ }^{39}$ bu hükmün içine alınmış ve sürenin başlangıcının ne zaman olduğunun belirsiz olması üzerine, kesinleşen kıymet takdirinin yapıldığı tarihten itibaren bir yıl geçmedikçe yeniden kıymet

35 Boran Güneysu (n 13) 30.

36 ibid 30-31.

37 ibid 31.

382004 sayılı İcra ve İflas Kanununun Bazı Maddelerinin Değiştirilmesine, 3182 sayılı Bankalar Kanunu’nun İki Maddesinin Yürürlükten Kaldırılmasına Dair Kanun, Kabul Tarihi: 09.11.1988, Yürürlüğe Giriş Tarihi: 25.11.1988 (RG 25.11.1988, S 20000).

394949 sayılı İcra ve İflâs Kanununda Değişiklik Yapılmasına Dair Kanun, Kabul Tarihi:17.7.2003, Yürürlük Tarihi: 30.07.2003 (RG 30.07.2003, S 25184). 
takdiri istenemeyeceği şeklinde düzenlenmiştir. Ancak daha sonra madde metninde bir yıl olarak düzenlenen süre 'iki yıl' olarak değiştirilmiştir ${ }^{40}$.

İcra ve İflâs Kanunu m.128’e kesinleşen kıymet takdiri için iki yıl geçmedikçe yeniden kıymet takdiri istenemeyeceğine ilişkin düzenlemenin eklenmesine ilişkin maddenin gerekçesinde ${ }^{41}$, "kötü niyetli ve mükerrer işlemleri önlemek için kesinleşen kıymet takdiri için iki yıl geçmedikçe yeniden kıymet takdiri istenmemesinin öngörüldüğü” yer almıştır. Ortaya çıkmaktadır ki bu düzenleme, mükerrer ve kötü niyetli işlemleri önlemek amacıyla konulmuştur ${ }^{42}$. Getirilen bu hüküm doktrinde, yapılan kıymet takdirinden sonra taşınmaz malın değerinde ortaya çıkacak büyük değişikliklerin göz önüne alınmaması sonucunu doğuracağı ve bundan da borçluların ve hatta alacaklarına tam olarak kavuşamayan alacaklıların da zarar göreceği sebebiyle eleştirilmiştir ${ }^{43}$.

\section{DEĞERLENDIRME}

7226 sayılı Kanun geçici madde 1 hükmünün ilk fikrasında sürelerin durdurulmasının "Covid-19 salgın hastalığının ülkemizde görülmüş olması sebebiyle yargı alanındaki hak kayıplarının önlenmesi amacıyla" yapıldığı yer almaktadır. Pandemi sebebiyle alınmış olan adli tedbirlerin ana amacının hak kayıplarının engellenmesi olduğundan hareket edildiğinde, icra takip işlemi niteliğinin dahi tartışmalı olduğu kıymet takdirinin ${ }^{44}$ yeniden yapılabilmesi için geçmesi gereken iki yıllık sürenin durduğu sonucuna ulaşmak, aslen daha büyük hak kayıplarına yol açabilir niteliktedir.

Taşınmazın değerinin tam ve doğru olarak tespit edilmesine ilişkin menfaat ile yeniden kıymet takdiri istenememesine ilişkin iki yıllık süreye ilişkin menfaat dengesinin doğru bir şekilde kurulması icap etmektedir. İcra ve İflâs Kanunu m.128a/III, c.1 hükmü niteliği itibariyle, kıymet takdirinin makul sürede tamamlanmasına yönelik bir tedbir olarak değerlendirilmeli ${ }^{45}$ ve bu hükümde yer alan iki yıllık sürenin işleyişinin durdurulması yolu ile mutlak bir hak olan mülkiyet hakkı ihlal edilmemelidir.

Doktrinde İIK m.128a/III, c.1 hükmünde yer alacak sürenin belirlenmesinde kötü niyetli işlemlerin önlenmesi ile taraf menfaatlerinin dengelenmesinin gerekeceğinin altı çizilerek, alacaklı ve borçlu menfaatlerinin korunması amacıyla, kıymet takdirinin iki yıl geçmedikçe yeniden yapılamayacağına ilişkin hükmün değiştirilmesi ve bu sürenin bir yıla indirilmesi önerilmiştir ${ }^{46}$. Ancak 7226 sayılı

405092 sayılı İcra ve İflâs Kanununda Değişiklik Yapılmasına Dair Kanun, Kabul Tarihi:12.2.2004, Yürürlük Tarihi: 21.02.2004 (RG 21.02.2004, S. 25380).

41 Madde gerekçesi için bkz. TBMM (S. Sayısı 113), Yasama Yılı: 2, Dönem 18.

42 Boran Güneysu (n 13) 206.

43 Ejder Yılmaz, İcra ve İflâs Kanunumuz Yine Değişti (değişikliklere ilişkin bazı düşünceler) (1989) (1) ABD, 105-135, 122 (Değişti).

44 İcra takip işlemine ilişkin ayrıntılı bilgi için bkz. Nilüfer Boran Güneysu, 'İcra Takip İşlemleri' (2012) 101 31-60; Aziz Serkan Arslan, İcra Takip İşlemleri (Yetkin 2018); Kıymet takdiri işleminin hukuki niteliğine ilişkin ayrıntılı bilgi için bkz. Boran Güneysu (n 13) 116 vd.

45 Boran Güneysu (n 13) 33.

46 ibid 207. 
Kanun geçici madde 1 hükmü ile iki yıllık sürenin işlemesinin durdurulacağ 1 sonucuna varılır ise fiili olarak geçen süre iki yıldan da uzun olacaktır.

Yargıtay İIK m.128a/III, c.1 düzenlemesini kamu düzenine ilişkin olarak kabul etmektedir ve bu sebeple de iki yıllık sürenin aşılmış olmasını mahkemenin resen dikkate alması gerektiği kanaatindedir ${ }^{47}$. Kıymet takdirinin kesinleşmesinden itibaren iki yıl içerisinde taşınmazın satılması gerekmektedir ancak kesinleşen kıymet takdirinin üzerinden iki yıl geçtikten sonra satış yapılması halinde icra mahkemesi bu hususu ihalenin feshi taleplerinde re'sen dikkate alacaktır. Lakin Yargitay, satışa esas teşkil kıymet takdir işleminin üzerinden iki yıllık yasal sürenin geçmiş olduğu hallerde, zarar unsurunun oluştuğunu kabul etmektedir ${ }^{48}$.

Görülmektedir ki, kıymet takdirinin kesinleşmesinden sonra iki yıllık süre içerisinde taşınmazın satılması halinde yeniden kıymet takdiri yapılmasına ihtiyaç olmamakla birlikte, aksi durum kamu düzeni niteliği taşımakta ve bu süreye uyulup uyulmaması icra mahkemesi tarafından re’sen dikkate alınmalıdır. Dolayısı ile İcra ve İflâs Kanunu ve Yargıtay kararlarında ortaya çıkmaktadır ki taşınmazın kıymeti, kıymet takdirinin kesinleşmesine ilişkin iki yıllık sürenin geçmesi halinde, her halde yeniden takdir edilmelidir. Lakin iki yıllık süre içerisinde ekonomik gelişmeler ve dalgalanmalar dikkate alındığında, taşınmazın değerinde değişiklik meydana gelebilecektir ${ }^{49}$. Hızlı gelişen ülkemizde farklı ekonomik yatırımların söz konusu olması, alt yapı faaliyetleri, ulaşım inşaatları gibi hususlar taşınmazın değerinde farklılık ortaya çıkarabilecektir. Bu sebepler dikkate alındığında madde hükmünde belirlenen iki yıllık süre, taşınmazın gerçek değerinin doğru kalabildiği maksimum süre olarak değerlendirilmelidir. Bu sürenin aşıldığı hallerde ise artık taşınmaza ilişkin yapılmış kıymet takdirinin taşınmazın gerçek ve doğru değerini yansıtmadığı kabul edilmelidir.

Tüm bu değerlendirmeler 1şığında, 7226 sayılı Kanun geçici madde 1 hükmünün lafzi yorumu ile İIK m.128a/III,c.l'de düzenlenen iki ylllk sürenin durmasının kabul edilmesi aslen cebri icra hukukunda korunması gereken menfaatler dengesine aykırılık teşkil edebilecektir. Dolayısı ile adli tedbirler çerçevesinde bu sürenin durmadığının kabul edilmesi düşünülebilir.

Covid-19 pandemisi sebebiyle ile aslen ekonomik gelişmelerin durmadığı, ekonomik devinimin devam ettiği ve hatta bu salgının ekonomik hayata etkisinin çoklu boyutu da dikkate alındığında, kıymet takdirine ilişkin olarak düzenlenmiş olan iki yıllık sürenin işlemesi bakımından 7226 sayılı Kanun geçici madde 1 hükmünün kabul edilmesinden öncesi ile bir fark olmaması gerekir. Hatta taşınmazın gerçek değerinin doğru tespiti ve düzenlenmiş olan iki yıllık sürenin daha da önem kazandığı söylenebilecektir. Ekonomik gelişmeler ve varlık fiyatlarındaki dalgalanmalar pandemi ile birlikte artarak devam etmektedir ve bu sebeple aslen bu sürenin durdurulmasina da gerek olmayabilir.

47 Yargitay 12. HD, E 2012/15306, K 2012/27755, T 25.09.2012; Yargitay 12. HD, E 2013/1902, K 2013/9342, T. 14.03.2013; Yargitay 12. HD, E 2013/3076, K 2013/11160, T 25.03.2013 (Lexpera Hukuk Bilgi Sistemi, Erişim Tarihi: 20.11.2021).

48 Yargitay 12. HD, E 2015/28132, K 2015/30325, T 03.12.2015 (Lexpera Hukuk Bilgi Sistemi, Erişim Tarihi: 20.11.2021). 
Kaldı ki İIK m.128a/III, c.2 hükmü doğal afetler ve imar durumundaki çok önemli değişiklikler meydana getiren benzer hallerde tarafların talebi ile yeniden kıymet takdiri yapılabilmesine imkan vermektedir. Bu çerçevede Covid-19 pandemisinin doğal afet olarak değerlendirilmesi ve tarafların her halde yeniden kıymet takdiri talep edilmesine imkân sağlanması gerekmektedir.

Dolayısı ile 7226 sayılı Kanun'un geçici madde 1 hükmünde yer alan İcra ve İflâs Kanunu’nda yer alan sürelerin duracağına ilişkin hükmün, İIK m.128a/III, c.l'deki sürenin ruhuna, felsefesine, korumak istediği menfaate aykırı düşündüğü sonucuna da varılabilmektedir.

Yargıtay da vermiş olduğu bir kararında, Bölge Adliye Mahkemesi tarafından karar verilen ihalenin feshine ilişkin karara karşı yapılan temyiz başvurusunda Bölge Adliye Mahkemesi kararını, taşınmazlar yönünden kesinleşen kıymet takdirinin yapıldığı tarihten itibaren iki yıldan fazla süre geçtiği, ilgili sürenin 7226 sayılı Kanun’la belirlenen durma süreleri içinde olmaması sebebiyle uzamasının da mümkün olmayacağı ve kesinleşen kıymet takdiri ile satış arasında iki yıldan fazla süre olmaması hususunun re’sen gözetilmesi gerektiği gerekçeleri ile doğru bularak, onamıştır ${ }^{50}$.

\section{SONUÇ}

Dünya genelinde ortaya çıkan ve Dünya Sağlık Örgütü tarafından 'pandemi' olarak ilan edilen Covid-19 salgını sebebiyle adli birtakım tedbirler alınması zorunluluğu doğmuştur. Bu tedbiler kapsamında 7226 sayılı Kanun’un geçici madde 1 hükmü ile İcra ve İflâs Kanunu ile takip hukukuna ilişkin sürelerin durması kabul edilmiştir.

50 Kararda “İIK’nun 128/a-2. maddesinde; "Kesinleşen kıymet takdirinin yapıldığı tarihten itibaren iki yıl geçmedikçe yeniden klymet takdiri istenemez" hükmüne yer verilmiştir. Hukuk Genel Kurulu’nun 26.02.1992 tarih ve 1992/4-70 E. - 1992/130 K. sayılı kararında da vurgulandığı üzere, İIK’nun 128. maddesinde öngörülen iki yıllık sürenin başlangıcı, sonradan kesinleşmesi koşulu ile kıymet takdirinin fiilen yapıldığı keşif tarihidir. Diğer taraftan, 7226 sayılı Kanunun Geçici 1. maddesi uyarınca 13/03/2020 tarihinden itibaren 30/04/2020 tarihinde kadar sürelerin işlemesinin durduğu, 30/04/2020 tarih ve 31114 sayılı Resmi Gazetede yayımlanan 2480 sayılı Cumhurbaşkanı Kararıyla durma süresinin 15/06/2020 tarihine kadar uzatıldığı, 7226 sayılı Kanunun Geçici 1. maddesi ile bu sürelerin, durma süresinin sona erdiği günü takip eden günden itibaren işlemeye başlayacağı, durma süresinin başladığı tarih itibarıyla, bitimine on beş gün ve daha az kalmış olan sürelerin, durma süresinin sona erdiği günü takip eden günden başlamak üzere on beş gün uzamış sayılacağı, bu nedenle 15/06/2020 tarihine kadar duran sürelerin bu tarihten itibaren yeniden işlemeye başladığı, uzamış sürenin son gününün ise 30/06/2020 tarihi olduğu anlaşılmıştır. Somut olayda, ihaleye konu taşınmazların kıymet takdiri işleminin, icra müdürlüğünce, 29/06/2018 tarihinde yaptırıldığı, ihalenin ise iki yıldan fazla süre geçtikten sonra 26.08.2020 tarihinde gerçekleştirildiği anlaşılmış olup, İ́K’nun 128/a-2. maddesinde öngörülen sürenin son günü olan 29.06.2020 tarihi, 7226 sayılı Kanunla belirlenen durma süreleri içinde olmadığından uzatılması da söz konusu olmayacaktır. O halde, borçluların şikâyet dilekçesinde, kendilerine yapılan satış ilanı tebliğ işleminin usulsüz olduğu iddiasına dayalı açık bir fesih isteminin bulunmaması ve İIK’nun 150/e maddesi uyarınca icra emrinin borçlulara 12.06.2018 tarihinde tebliğ edilmesinden sonra alacaklının 26.10.2018 tarihinde satış avansını yatırması ve 24.05.2019 tarihinde de satıs talep etmiş olması nedeniyle anılan bu iki hususun fesih nedeni yapılması doğru değil ise de; 391 ada 13 parselin ihale bedelinin, taşınmazın tahmini değerinin yüzde ellisine satış masraflarının eklenmesiyle oluşan miktarı karşılamadığının anlaşılması ve tüm taşınmazlar yönünden kesinleşen kıymet takdirinin yapıldığı 29/06/2018 tarihinden itibaren iki ylldan fazla süre geçtikten sonra ihalenin gerçekleştirilmesi hususunun da re’sen gözetilmesi gerektiğinden, Bölge Adliye Mahkemesince ihalenin feshine karar verilmiş olması sonucu itibariyle doğru olup kararın onanması gerekmiştir." sonucuna varılmıştır, Yargitay 12. HD, E 2021/3183, K 2021/4769, T 17.05.2021 (https:// karararama.yargitay.gov.tr, Erişim Tarihi: 24.08.2021). 
Bu düzenleme kapsamında İ̇K m.128a/III, c.1 hükmündeki iki yıllık sürenin durmasını kabul eden görüşün gerekçesi kabul edilmekle beraber farklı düşünmenin de mümkün olduğu anlaşılmaktadır.

Cebri icra hukukunda kıymet takdiri bakımından esas olan taşınmaza ilişkin değer tespitinin doğru ve tam bir şekilde yapılmasıdır. Bu amacı itibariyle de kıymet takdirine ilişkin düzenlemeler hem takip alacaklısının hem takip borçlusunun hem de taşınmaz üzerindeki diğer hak sahiplerinin menfaatlerini koruyucu niteliktedir. İİK m.128a/III,c.1'de yer alan iki yıllık süreyi de bu kapsamda değerlendirmek gerekmektedir. Hüküm, aslen kötü niyetli ve mükerrer işlemleri önlemek ve takibi sürüncemede bırakmamak amacı ile kabul edilmiş olmakla aslen kıymet takdirinin makul sürede tamamlanmasına yönelik bir tedbir olarak kabul edilmelidir. Kesinleşen kıymet takdirinin üzerinden iki yıl geçtikten sonra satış yapılması halinde zarar unsurunun her halde oluştuğu Yargıtay tarafından kabul edilmektedir ve icra mahkemesi de bu hususu ihalenin feshi taleplerinde re'sen dikkate alacaktır.

7226 sayılı Kanun geçici madde 1 hükmü ile iki yıllık sürenin işlemesinin durdurulacağı sonucuna varılır ise fiili olarak geçen süre iki yıldan uzun olacaktır. Bu durumda da taşınmazın değerinin tam ve doğru olarak tespit edilmesine ilişkin menfaat ile yeniden kıymet takdiri istenememesine ilişkin iki yıllık süreye ilişkin menfaat dengesinin gözden geçirilmesi gerekmektedir. Nitekim Yargıtay da İIK m.128a/III, c.1'de yer alan iki yıllık sürenin 7226 sayılı Kanun ile belirlenen durma sürelerinin içinde olmadığını ve bu sebeple de uzamasının mümkün olmayacağına ilişkin karar vermiştir ${ }^{51}$.

Özellikle altının çizilmesi gereken bir diğer husus ise, İIK m.128a/III,c.2 hükmünün doğal afetler ve imar durumundaki çok önemli değişiklikler meydana getiren benzer hallerde tarafların talebi ile yeniden kıymet takdiri yapılabilmesine imkan verdiğidir. Bu düzenleme ise aslen kanunun ruhunun süreye bağlılıktan öte taşınmazın değerinin doğru tespit edilmesine öncelik verdiğini gösterir niteliktedir.

\section{KAYNAKÇA}

Arslan A Z, İcra Takip İşlemleri (Yetkin 2018).

Arslan A Z, 'Covid-19 Salgını Sebebiyle İcra Takiplerine İlişkin Düzenlemelerin Değerlendirilmesi', (2020) (148) TBB Dergisi, 197-234.

Arslan R, Yılmaz E, Taşpınar-Ayvaz S ve Hanağası E, İcra ve İflas Hukuku (6. Baskı, Yetkin Yayınları 2020).

Aslan V, 'COVID-19 Salgını Sebebiyle Uygulanan Sokağa Çıkma Kısıtlamalarının 1982 Anayasası'na Uygunluğu', (2020) LXXVIII (2), İstanbul Hukuk Mecmuası, 809-835.

Atalay O ve Özekes M, ‘7226 Sayılı Kanun ile İcra ve İflâs Kanunu m.330 Hükmünü Uygulayan Cumhurbaşkanlığg Kararı (2279 Sayılı) Çerçevesinde Ortaya Çıkan Bazı Sorular ve Tartışmalara Cevaplar', in Muhammet Özekes (ed), Covid-19 salgınının Hukuki Boyutu-Hukukun Tüm Alanlarında Değerlendirmeler, (On İki Levha 2020) 159-186.

Atalı M, Ermenek, İ ve Erdoğan, E: İcra ve İflas Hukuku (3. Bası, Yetkin Yayınları 2020).

Atalı M ve Erdoğan E, 'COVİD-19 Salgınının İcra ve İflâs Hukuku Alanına Etkileri', (2020) LXXVIII (2) İstanbul Hukuk Mecmuası, 395-416.

Boran Güneysu N, Nilüfer Boran Güneysu, 'İcra Takip İşlemleri’ (2012) (101), 31-60.

51 Yargitay 12. HD, E 2021/3183, K 2021/4769, T 17.05.2021 (https://karararama.yargitay.gov.tr, Erişim Tarihi: 24.08.2021). 
Boran Güneysu N, İcra Hukukunda Taşınmazların Kıymet Takdiri (Yetkin Yayınları 2020).

Çiftçi P, İcra Hukukunda Menfaat Dengesi (Adalet 2010).

Dönmez M, İcra ve Íflâs Hukukunda Taşınmaz Malların Paraya Çevrilmesi (Vedat Kitapçılık 2010).

Kiraz T Ö, 'Fevkalâde Hallerde Mühlet ve Tatil (İIK. md.317-330)', (2000) 73 (2) Manisa Barosu Dergisi 7-20.

Kuru B, İcra ve İflas Hukuku, C. II (3. Baskı, Evrim 1990).

Kuru B, İcra ve İflas Hukuku El Kitabı (2. Bask1, Adalet 2013) (El Kitabı).

Namlı M, İcra Hukukunda Taşınmaz Malların Haczi ve Paraya Çevrilmesi (On İki Levha Yayıncılık 2019).

Oskay M, Koçak, C, Deynekli A ve Doğan A, İIK Şerhi (Madde 100-176/b), C. 3 (Turhan Kitapevi 2007).

Özekes M, 'İcra Hukukunda Temel Haklar ve İlkeler, (Adalet 2009) (Temel Haklar).

Pekcanıtez H, ‘4949 sayılı Kanun'la, İcra Hukukunda Yapılan Değişikliklerin Değerlendirilmesi’ (2003) (49) TBB Dergisi 137-258 (Değişiklik).

Pekcanıtez H, '2279 sayılı Cumhurbaşkanı (Fevkalâde Mühlet) Kararı ile 7226 Sayılı Kanunun Geçici 1. Maddesinin Birlikte Değerlendirilmesi, in Muhammet Özekes (ed), Covid-19 salgınının Hukuki Boyutu-Hukukun Tüm Alanlarında Değerlendirmeler (On İki Levha 2020) 143-157 (Covid).

Pekcanıtez H ve Erişir E, 'Koronavirüs (Covid-19) Salgınına Karşı Alınan, Medeni Usûl ve İ́cra İflâs Hukukunu İlgilendiren Önlemler’ (Legal Blok, 3 Haziran 2020) < https://legal.com.tr/blog/genel/koronaviruscovid-19-salginina-karsi-alinan-medeni-usul-ve-icra-iflas-hukukunu-ilgilendiren-onlemler/ > Erişim Tarihi 14 Şubat 2020.

Pekcanıtez H, Atalay O, Sungurtekin-Özkan M ve Özekes M, İcra ve İflas Hukuku (7. Bası, On İki Levha Yayıncılık 2020).

Yılmaz E, 'Olağanüstü Durumlarda Borçlulara Süre Verilmesi ve İcra Takiplerinin Durdurulmasi', (1977) IX BATIDER 153-191.

Yılmaz E, İcra ve İflâs Kanunumuz Yine Değişti (değişikliklere ilişkin bazı düşünceler) (1989) (1) ABD, 105135 (Değişti). 